\begin{tabular}{|l|l|l|}
\hline \multicolumn{2}{|c|}{ PublisherInfo } \\
\hline \hline PublisherName & $:$ & BioMed Central \\
\hline \hline PublisherLocation & $:$ & London \\
\hline \hline PublisherImprintName & $:$ & BioMed Central \\
\hline \hline
\end{tabular}

\title{
Costs, prognosis and quality of life following renal support in the ICU
}

\begin{tabular}{||l|l|l||}
\hline \multicolumn{2}{|c||}{ ArticleInfo } \\
\hline \hline ArticleID & $:$ & 4266 \\
\hline \hline ArticleDOI & $:$ & $10.1186 /$ ccf-2001-2881 \\
\hline \hline ArticleCitationID & $:$ & 2881 \\
\hline \hline ArticleSequenceNumber & $:$ & 54 \\
\hline \hline ArticleCategory & $:$ & Paper Report \\
\hline ArticleFirstPage & $:$ & 1 \\
\hline \hline ArticleLastPage & $:$ & 3 \\
\hline \hline & & RegistrationDate : 2001-1-9 \\
ArticleHistory & $:$ & OnlineDate \\
\hline \hline ArticleCopyright & $:$ & Biomed Central Ltd2001-9 \\
\hline \hline ArticleGrants & $:$ & \\
\hline \hline ArticleContext & $:$ & 1305433 \\
\hline \hline
\end{tabular}


Aff1 St George's Hospital, London, UK

\section{Keywords}

Acute renal failure, costs of care, mortality, multiple organ failure, quality of life

\section{Comments}

This retrospective uncontrolled study reiterates the high hospital mortality associated with acute renal failure (ARF) in the ICU presumably since it occurs as part of multiple organ failure (MOF). However, following hospital discharge the increase in mortality is small and probably doesn't differ from other groups of ICU survivors. The costs associated with ARF are high, although the authors comment that renal replacement therapy (RRT) is cost-effective since quality of life (QOL) is acceptable in the majority. However, the low response rate to QOL questionnaires makes this conclusion less robust, and may well reflect selection-bias, with those with a poor QOL being unable to reply. The study is based on clinical decisions made 8 years ago and may not reflect present practices for RRT, although the premise that RRT improves survival is still based on retrospective evidence, since prospective studies would be considered unethical. It is reassuring however, that renal function is restored in the majority of survivors following discharge form the ICU, and that dependence on chronic renal replacement therapy is low.

\section{Introduction}

Prognosis remains poor for intensive care patients in ARF despite advances in renal supportive therapies, presumably since this reflects one aspect of MOF. This study examines the costs, longer-term outcome (5-year) and QOL in patients requiring RRT in the ICU.

\section{Methods}

- Retrospective observational cohort study of 23-bed multidisciplinary ICU in Finland

- 2 year period of ICU admissions (1992-1993) 
- Outcomes in patients who required RRT: mortality, quality of life in survivors at 6 months following ICU discharge (Nottingham Health Profile and ADL index), and ICU costs (calculated from individual patient's TISS scores)

- Exclusions: patients with end-stage renal failure

\section{Results}

- Of 3447 patients, 69 (2\%) required RRT. The cohort included 885 neurosurgical patients (none required RRT), and 1611 cardiac surgery patients (19 required RRT).

- ICU mortality 34\%, hospital mortality 45\%, 6-month mortality 55\%, 5-year mortality $65 \%$.

- ARF in conjunction with MOF occurred in $71 \%$.

- Overall length of stay in the ICU was the same for survivors and non-survivors, although survivors had a significantly shorter ICU stay prior to RRT.

- Cost per ARF 6-month survivor was $\$ 80000$.

- Response to mailed QOL questionnaires was 50\%, and loss of energy and limited physical mobility were the major complaints. In total $36 \%$ were dependent on external help for heavy housework.

\section{References}

1. Korkeila M, Ruokonen E, Takala J: Costs of care, long-term prognosis and quality of life in patients requiring renal replacement therapy during intensive care. Intensive Care Med. 2001, 26: 1824-1831 